\title{
El derecho fundamental a la libertad física: re- flexiones a partir de la Constitución, el Código Procesal Penal y la jurisprudencia del Tribunal Constitucional
}

\author{
LUIS ALBERTO HUERTA GUERRERO*
}

SUMARIO: INTRODUCCIÓN.- I. PROHIBICIÓN DE DETENCIONES ILEGALES.- II. PROHIBICIÓN DE DETENCIONES ARBITRARIAS.- III. DERECHO AL TRASLADO INMEDIATO ANTE UNA AUTORIDAD JUDICIAL.- IV. CARÁCTER EXCEPCIONAL DE LA DETENCIÓN JUDICIAL.- V. DERECHO AL PLAZO RAZONABLE DE LA DETENCIÓN JUDICIAL PREVENTIVA.- VI. DERECHO A LA PROTECCIÓN JUDICIAL DE LA LIBERTAD FÍSICA.- VII. REFLEXIONES FINALES.

\section{INTRODUCCIÓN}

La libertad física es un derecho fundamental reconocido en la Constitución Política de 1993 y los tratados sobre derechos humanos. Se trata de un derecho particularmente importante, pues, por lo general, las medidas orientadas a garantizar el orden público están relacionadas con normas que limitan su ejercicio, situación que se pone de manifiesto de modo particular en coyunturas de alta inseguridad ciudadana. Tales restricciones, generalmente, se enmarcan dentro del desarrollo de las investigaciones de un delito y de los procesos penales, lo que explica la necesidad de que los operadores jurídicos involucrados (policías, fiscales, jueces y abogados defensores) interpreten y apliquen de forma adecuada el marco normativo vigente que regula los supuestos en los que corresponde privar a una persona de su libertad física.

En este sentido, el Código Procesal Penal de 2004, en el artículo VI de su Título Preliminar, señala de forma clara lo siguiente respecto de las medidas por medio de las cuales, en el marco de un proceso penal, se restringen los derechos fundamentales, entre ellos la libertad física:

Legalidad de las medidas limitativas de derechos.- Las medidas que limitan derechos fundamentales, salvo las excepciones previstas en la Constitución, sólo podrán dictarse por la autoridad judicial, en el modo, forma y con las garantías previstas por la Ley. Se impondrán mediante resolución motivada, a instancia de la parte procesal legitimada. La orden judicial debe sustentarse en suficientes elementos de convicción, en atención a la naturaleza y finalidad de la medida y al derecho fundamental objeto de limitación, así como respetar el principio de proporcionalidad.

* Es profesor de Derecho Constitucional y Derecho Procesal Constitucional en la Pontificia Universidad Católica del Perú, la Universidad Nacional Mayor de San Marcos y la Academia de la Magistratura del Perú. 
En términos generales, la Constitución de 1993 no contempla una redacción ordenada y completa de todas las garantías y facultades inherentes a la libertad física como derecho fundamental, por lo que resulta imprescindible acudir al Derecho internacional de los derechos humanos para su análisis, cuyas disposiciones son más claras y ordenadas. Además, son conformes con lo establecido en la Cuarta Disposición Final y Transitoria de la Constitución de 1993, que establece que «las normas relativas a los derechos y a las libertades que la Constitución reconoce se interpretan de conformidad con la Declaración Universal de Derechos Humanos y con los tratados y acuerdos internacionales sobre las mismas materias ratificados por el Perú».

Así, una revisión de la Convención Americana sobre Derechos Humanos (artículo 7) y del Pacto Internacional de Derechos Civiles y Políticos (artículo 9) permite concluir que las garantías y facultades mínimas inherentes a la libertad física son las siguientes:

- prohibición de detenciones ilegales;

- prohibición de detenciones arbitrarias;

- derecho a ser trasladado inmediatamente ante una autoridad judicial;

- carácter excepcional de la detención judicial preventiva;

- plazo razonable de la detención judicial preventiva; y

- protección judicial de la libertad física.

En el presente trabajo, nuestro análisis seguirá el orden de estas garantías y facultades con el propósito de identificar su desarrollo a partir de lo dispuesto en la Constitución Política de 1993, así como en la jurisprudencia del Tribunal Constitucional peruano. Este último deberá ser observado por los operadores jurídicos responsables de investigar y sancionar los actos considerados como delitos en nuestro ordenamiento jurídico en concordancia con lo dispuesto en la legislación procesal penal vigente, que incluye algunos artículos del Código Procesal Penal de 1991 y el Código Procesal Penal de 2004.

\section{PROHIBICIÓN DE DETENCIONES ILEGALES}

La primera garantía de la libertad física que debe ser observada por los operadores jurídicos es la prohibición de detenciones ilegales. Estas son las que se producen al margen de los supuestos de hecho y del procedimiento previsto en el ordenamiento jurídico de cada país para que proceda la privación de libertad de una persona.

$\mathrm{Al}$ respecto, el Pacto Internacional de Derechos Civiles y Políticos señala en su artículo 9, inciso 1, lo siguiente: «Nadie podrá ser privado de su 
libertad, salvo por las causas fijadas por ley y con arreglo al procedimiento establecido en ésta» (subrayado nuestro).

Por su parte, la Convención Americana sobre Derechos Humanos, en su artículo 7, inciso 2, señala: «Nadie puede ser privado de su libertad física, salvo por las causas y en las condiciones fijadas de antemano por las Constituciones Políticas de los Estados Partes o por las leyes dictadas conforme a ellas» (subrayado nuestro).

$\mathrm{Al}$ analizar esta disposición de la convención, la Corte Interamericana de Derechos Humanos ha precisado que ${ }^{1}$ :

[...] nadie puede ser privado de la libertad personal sino por las causas, casos o_circunstancias expresamente tipificadas en la ley (aspecto material) pero, además, con estricta sujeción a los procedimientos objetivamente definidos por la misma (aspecto formal) (subrayado nuestro).

EL DERECHO FUN-

DAMENTAL A LA

LIBERTAD FÍSICA:

REFLEXIONES

A PARTIR DE LA

CONSTITUCIÓN,

EL CÓDIGO PRO-

CESAL PENAL Y LA

JURISPRUDENCIA

DEL TRIBUNAL

CONSTITUCIONAL

En consecuencia, la privación de la libertad física solo puede efectuarse en ciertos casos y de acuerdo a los procedimientos previstos en la Constitución o la ley. De lo contrario, estaremos ante una privación ilegal de la libertad. Por ello, corresponde identificar en qué casos la detención de una persona procede en nuestro país y cuál es el procedimiento a seguir en tales situaciones.

\section{I.1. Supuestos en que procede la privación de libertad de una persona}

El artículo 2, inciso 24, de la Constitución de 1993 establece dos disposiciones de especial importancia para analizar de forma adecuada cuáles son los supuestos en que procede la privación de la libertad física de una persona. Al respecto señala:

Toda persona tiene derecho: [ ...]

A la libertad y seguridad personales. En consecuencia: [...]

b) No se permite forma alguna de restricción de la libertad personal, salvo en los casos previstos por la ley. [...]

f) Nadie puede ser detenido sino por mandamiento escrito y motivado del juez o por las autoridades policiales en caso de flagrante delito. [...]

De la lectura de estos artículos, se concluye que, a nivel constitucional, solo se establece un supuesto de privación de libertad de las personas - la comisión de un delito en situación de flagrancia-, y se deja a la ley el establecimiento de los otros casos en los que procede restringir la libertad física. La referencia que hace el texto constitucional a la resolución judicial debidamente motivada, antes que un supuesto de hecho

1 Corte Interamericana de Derechos Humanos. Caso Gangaram Panday, sentencia sobre el fondo del 21 de enero de 1994, parágrafo 47. 
en el que procede una detención, se relaciona con el procedimiento a seguir para tal efecto, tema que será abordado más adelante.

\section{I.1.1 Flagrante delito}

La Constitución de 1993 establece que una persona puede ser privada de libertad si es encontrada en situación de flagrante delito. Corresponde a la legislación procesal penal definir qué se entiende como tal y a la jurisprudencia constitucional precisar si dicha opción es acorde con la Constitución. Sin embargo, en el caso peruano ha ocurrido algo singular: primero se construyó una línea jurisprudencial sobre la materia y, luego, se emitieron las normas legales respectivas.

Una primera definición normativa sobre la flagrancia estuvo prevista en el Código Procesal Penal de 1991 (decreto legislativo 638)², que nunca llegó a entrar en vigencia en su totalidad. Precisamente, uno de estos artículos fue aquel que definía la flagrancia, razón por la que correspondía a los órganos jurisdiccionales del Estado asumir una posición sobre la materia. En el caso específico del Tribunal Constitucional, se fue construyendo una definición sobre el flagrante delito a través de su jurisprudencia.

Así, a finales de 1998, en una de las primeras oportunidades en las que el Tribunal se pronunció sobre este tema, señaló ${ }^{3}$ :

La excepción (a la libertad física) se produce cuando la propia persona se aleja de su dignidad y se relaciona con el delito. En esta eventualidad la persona sólo puede ser detenida por orden escrita y motivada del Juez o por la autoridad policial en caso de flagrante delito; vale decir, por evidencias en el momento mismo de la comisión del hecho delictuoso o posterior a tal acto cuando subsisten evidencias del delito; esta precisión jurídica se realiza en virtud que la Constitución Política prescribe «en caso de flagrante delito», no necesariamente in fragante, es decir, en el momento mismo de la producción del evento. Lo contrario significaría que aún existiendo notorias evidencias del hecho punible, después de la perpetración, el presunto responsable goce aún de libertad; y, además, desde luego, para la detención debe existir nexo de causalidad entre el delito y la conducta del supuesto infractor quien jurídicamente es inocente hasta que se pronuncie sentencia sobre su responsabilidad.

Sobre la misma línea, el tribunal reiteró su posición sobre el flagrante delito con los siguientes fundamentos ${ }^{4}$ :

2 Publicado el 27 de abril de 1991 en el diario oficial El Peruano.

3 STC $975-96-\mathrm{HC}$ publicada el 10 de setiembre de 1998, fundamento 1 . Similar razonamiento se encuentra en la STC 992-96-HC, publicada el 24 de setiembre de 1998, fundamento 1. En el primer caso la demanda fue declarada improcedente y en el segundo infundada, pero por temas diferentes al del flagrante delito.

4 STC 818-98-HC, publicada el 25 de mayo de 1999, fundamento 3 . En este caso, la demanda fue declarada fundada, pues la detención del beneficiario de la demanda - detenida por presunta posesión de drogas- se efectuó sin que existiera orden judicial o flagrante delito. En su decisión, el Tribunal señaló que «[...] ninguna investigación preliminar sobre tráfico ilícito de drogas puede 
Se está ante un caso de [flagrante delito] cuando se interviene u observa [a una persona] en el mismo momento de [la] perpetración [del delito] o cuando posteriormente a ella, [...] existen hechos o pruebas evidentes, sustentados en la técnica o la ciencia, que demuestren la producción del delito. Aspecto diferente es pronunciarse por la culpabilidad del detenido, que solamente se expresa mediante sentencia judicial.

En consecuencia, en un primer momento el tribunal asumió una posición en la que consideraba dentro del concepto de flagrancia, no solo los casos en los que una persona era detenida en el mismo acto de la comisión de un delito, sino también aquellos en los que una persona era encontrada con evidencias de haberlo cometido.

Con posterioridad, a partir de 2001, el tribunal restringió el concepto de flagrante delito y llegó a señalar que «la flagrancia supone la aprehensión del autor del hecho delictivo en el preciso momento de la comisión del mismo [sic] $»^{5}$.

Asimismo, descartó la posibilidad de interpretar la Constitución en el sentido de permitir la privación de libertad de una persona en situación de cuasi flagrancia, por cuanto la Constitución no alude a este concepto, «por lo que no puede habilitarse subrepticiamente supuestos de detención no contemplados constitucionalmente, sencillamente, por aplicación del principio de interpretación según el cual, las normas [que] establecen excepciones, deben ser interpretadas restrictivamente» ${ }^{6}$.

A modo de ejemplo, dentro de casos resueltos por el tribunal en los que calificó como incorrectas determinadas interpretaciones sobre el flagrante delito, se puede mencionar el hábeas corpus presentado a favor de varias personas que fueron detenidas con motivo de la denominada Marcha de los Cuatro Suyos (realizada en julio de 2000). En la sentencia respectiva, el tribunal declaró fundada la demanda y precisó que no puede ampliarse el concepto de flagrante delito hasta el extremo de pretender que la simple cercanía al lugar donde acontece un delito es por sí misma elemento objetivo que configura ese supuesto de hecho, pues con tal criterio «todas las personas, incluyendo autoridades distintas a la [Policía], estarían inmersas en la pretendida flagrancia»?

En este sentido, en un segundo momento, el Tribunal Constitucional optó por una interpretación restrictiva de la flagrancia, al entender como tal la situación en la que una persona es detenida en el mismo momento en el que cometía un delito.

legitimar la detención de cualquier persona si no se acredita con hechos evidentes la configuración de los elementos constitutivos del delito. El hecho de encontrar droga fuera del inmueble del investigado no acredita la existencia de flagrante delito porque falta el nexo de causalidad entre el lugar de ubicación de la droga y el detenido».

5 Resolución 125-2001-HC/TC, publicada el 3 de agosto de 2001, fundamento 3 .

6 STC 1318-2000-HC, publicada el 13 de abril de 2001, fundamento 3.

7 STC 1324-2000-HC, publicada el 27 de marzo de 2001.

EL DERECHO FUN-

DAMENTAL A LA

LIBERTAD FÍSICA:

REFLEXIONES

A PARTIR DE LA

CONSTITUCIÓN,

EL CÓDIGO PRO-

CESAL PENAL Y LA

JURISPRUDENCIA

DEL TRIBUNAL

CONSTITUCIONAL 
Esta fue, de alguna manera, la tendencia de la jurisprudencia del Tribunal Constitucional hasta que en 2003 fue emitida la ley 27934, Ley que Regula la Intervención de la Policía y del Ministerio Público en la Investigación Preliminar ${ }^{8}$, cuyo artículo 4 definió la flagrancia de la siguiente manera:

A efectos de la presente ley se considera que existe flagrancia cuando la realización del hecho punible es actual y, en esa circunstancia, el autor es descubierto, o cuando el agente es perseguido y detenido inmediatamente de haber realizado el acto punible o cuando es sorprendido con objetos o huellas que revelen que acaba de ejecutarlo.

Un año después, similar definición fue incorporada en el Código Procesal Penal de 2004, cuyo artículo 259 (sobre la detención policial) establecía en su texto original lo siguiente?

Existe flagrancia cuando la realización del hecho punible es actual y, en esa circunstancia, el autor es descubierto, o cuando es perseguido y capturado inmediatamente de haber realizado el acto punible o cuando es sorprendido con objetos o huellas que revelen que acaba de ejecutarlo.

En términos generales, tanto la definición de la ley 27934 como del Código Procesal Penal de $2004^{10}$ coincidían con los alcances sobre el flagrante delito precisadas en un primer momento en la jurisprudencia del Tribunal Constitucional (1998-2000), mas no con la interpretación restrictiva (2001-2002) que, paulatinamente, sería dejada de lado. Esta concordancia continuó en los fallos emitidos por el Tribunal con posterioridad a la promulgación del nuevo Código Procesal Penal, a la vez que se perfeccionó.

En este sentido, la tendencia jurisprudencial del Tribunal Constitucional sobre la definición del flagrante delito se concretó de la siguiente manera ${ }^{11}$ :

[...] la flagrancia en la comisión de un delito requiere el cumplimiento de cualquiera de los dos requisitos siguientes: a) la inmediatez temporal, es decir, que el delito se esté cometiendo o se haya cometido momentos antes; $y$, b) la inmediatez personal, es decir, que el presunto delincuente se encuentre en el lugar de los hechos, en el momento de la comisión del delito, y esté relacionado con el objeto o los instrumentos del delito.

Sin embargo, en 2007, el Poder Ejecutivo expidió un conjunto de decretos legislativos orientados a fortalecer la lucha contra el crimen

8 Publicada el 12 de febrero de 2003 en el diario oficial El Peruano.

9 El nuevo Código Procesal Penal fue aprobado mediante el decreto legislativo 957, publicado el 29 de julio de 2004 en el diario oficial El Peruano.

10 El hecho de que la definición sobre el flagrante delito aparezca en dos normas diferentes demuestra una falta de técnica legislativa sobre el tema, pues dicha definición solo debe estar en una norma.

11 Se pueden citar al respecto la STC 2617-2006-PHC, fundamento 5, publicada el 31 de agosto del 2006, la STC 1923-2006-PHC, fundamento 5, publicada el 18 de junio del 2006 y la STC 7376-2005$\mathrm{HC}$, fundamento 4, publicada el 5 de julio de 2006. 
organizado, al amparo de las facultades delegadas por el Congreso de la República mediante la ley $29009^{12}$. En dos de estas normas, el decreto legislativo $983^{13}$ y el decreto legislativo $989^{14}$, el flagrante delito fue definido de una manera mucho más amplia, como se aprecia a continuación:

[...] existe flagrancia cuando el sujeto agente es descubierto en la realización del hecho punible, o acaba de cometerlo, o cuando:

a) Ha huido y ha sido identificado inmediatamente después de la perpetración del hecho punible, sea por el agraviado, o por otra persona que haya presenciado el hecho, o por medio audiovisual o análogo que haya registrado imágenes de éste y, es encontrado dentro de las 24 horas de producido el hecho punible.

b) Es encontrado dentro de las 24 horas después de la perpetración del delito con efectos o instrumentos procedentes de aquél o que hubieren sido empleados para cometerlo o con señales en sí mismo o en su vestido que indiquen su probable autoría o participación en el hecho delictuoso.

Esta definición de flagrante delito, como era de esperarse, generó dudas en su compatibilidad con la jurisprudencia del Tribunal Constitucional. Además, nunca quedaron en claro las razones para modificar el texto del nuevo Código Procesal Penal de 2004, que solo había entrado en vigencia en determinados distritos judiciales. En su momento, la Defensoría del Pueblo se pronunció sobre estos decretos legislativos al señalar lo siguiente ${ }^{15}$ :

[...] la ampliación de los supuestos de flagrancia contemplados en los decretos legislativos 983 y 989 resultan inconstitucionales, al no contemplar adecuadamente los requisitos de percepción directa de la comisión del delito, inmediatez temporal e inmediatez personal. Esta ampliación, asimismo, puede generar serios problemas en la interpretación y aplicación de los citados decretos legislativos, lo que constituye una amenaza a la libertad física de toda persona. El supuesto de flagrancia como una causa para privar de libertad a una persona debe ser una medida excepcional y tener un desarrollo legislativo preciso, que no permita acudir a ella más allá de los supuestos en los que razonablemente cabe considerar que existe flagrancia en la comisión de un delito.

Contra los decretos legislativos 983 y 989 fue presentada una demanda de inconstitucionalidad, sobre la cual el tribunal se ha pronunciado entre otras normas, el artículo 259 del Código Procesal Penal de 2004.

14 Publicado el 22 de julio de 2007 en el diario oficial El Peruano. El decreto legislativo 989 modificó la ley 27934, Ley que Regula la Intervención de la Policía y del Ministerio Público en la Investigación Preliminar.

15 Defensoría del Pueblo. Análisis de los decretos legislativos promulgados al amparo de las facultades otorgadas por la Ley $N^{\circ}$ 29009. Lima: Defensoría del Pueblo, 2008, pp. 64-65.

EL DERECHO FUN-

DAMENTAL A LA LIBERTAD FÍSICA: REFLEXIONES

A PARTIR DE LA CONSTITUCIÓN, EL CÓDIGO PROCESAL PENAL Y LA JURISPRUDENCIA DEL TRIBUNAL CONSTITUCIONAL 
recién en el año 2010. Antes de que esto ocurra, sin embargo, se produjo una nueva reforma sobre la definición legal del flagrante delito.

En efecto, mediante la ley 29372, publicada el 9 de junio de 2009, se modificó nuevamente el artículo 259 del Código Procesal Penal de 2004 con el siguiente texto: «Existe flagrancia cuando la realización de un hecho punible es actual y en esa circunstancia, el autor es descubierto o cuando es perseguido y capturado inmediatamente después de haber realizado el acto punible o cuando es sorprendido con objetos o huellas que revelan que acaba de ejecutarlo».

En este sentido, con la ley 29372 se volvió al texto original del artículo 259 del Código Procesal Penal de $2004^{16}$, razón por la cual el Tribunal Constitucional declaró finalmente que, respecto de la demanda de inconstitucionalidad presentada contra los decretos legislativos 983 y 989 , se había producido la sustracción de la materia ${ }^{17}$.

Además, el tribunal señaló que la definición de flagrancia prevista mediante la ley 29372 resultaba acorde con su jurisprudencia. En este sentido, si no hubiera sido por esta norma, quizás hubiera tenido que pronunciarse sobre la inconstitucionalidad de los decretos legislativos impugnados. Ello queda claro en la parte final del fundamento primero de la sentencia, en la cual se señala:

En relación al artículo $3^{\circ}$ del Decreto Legislativo № 983 que modifica el artículo 259 del Nuevo Código Procesal Penal, que regulaba la flagrancia, se ha producido la sustracción de la materia porque la Ley No 29372 ha definido la flagrancia en términos, ahora sí, acordes con la jurisprudencia del Tribunal Constitucional (sentencias $\mathrm{N}^{\circ}$ 1958-2008-PHC; $\mathrm{N}^{\circ}$ 5423-2008-PHC y $\left.\mathrm{N}^{\circ} 1871-2009-\mathrm{PHC}\right)^{18}$, y no como se proponía en la legislación modificada, extendiendo dicha situación a las 24 horas posteriores a la comisión del delito (subrayado nuestro).

En nuestra opinión, con este fallo se cierra un ciclo de dudas e incertidumbres sobre la definición de la flagrancia en nuestro ordenamiento jurídico. Sin embargo, queda pendiente evaluar la forma en que dicho concepto es aplicado en los hechos por la Policía Nacional del Perú, lo

16 Un problema de técnica legislativa se aprecia en la ley 29372, pues en ella se señala de forma expresa que se estaba modificando el artículo 259 aprobado mediante el decreto legislativo 957 del nuevo Código Procesal Penal. Aunque, en realidad, estaba modificando los decretos legislativos 983 y 989 , a los cuales no hace mención alguna. Si somos estrictos, el error del texto de la ley 29372 implica que se estaba modificando una norma cuyo texto original había sido derogado.

17 STC 12-2008-PI

18 De las tres resoluciones a las que hace referencia el tribunal, interesa de modo particular la STC 5423-2008-TC, publicada el 18 de junio de 2009, pues en ella precisó lo siguiente (fundamento 10): «[...] la flagrancia debe entenderse como una evidencia del hecho delictuoso, por lo que sólo se constituirá cuando exista un conocimiento fundado, directo e inmediato del hecho punible que se viene realizando o que se acaba de realizar. La mera existencia de sospechas o indicios no es un elemento suficiente para constituir la flagrancia. En este sentido, lo que justifica la excepción al principio constitucional de la reserva judicial para privar la libertad en los supuestos de flagrancia es la inmediatez temporal y personal del hecho delictuoso, lo que supone la imposibilidad de obtener una orden judicial previa». 
que implica un trabajo de campo particularmente interesante, todavía pendiente de realizarse.

\section{I.1.2 Casos previstos por la ley}

La Constitución de 1993 (artículo 2, inciso 24, literal b) señala que «no se permite forma alguna de restricción de la libertad personal, salvo en los casos previstos por la ley [...]». En consecuencia, la ley es la norma llamada a precisar los casos que permiten o habilitan la privación de libertad de una persona. Tales supuestos de hecho se presentan por lo general como:

1. conductas consideradas como delitos y sancionadas con pena privativa de libertad, aspecto regulado en el Código Penal;

2. supuestos de hecho que habilitan ordenar la detención preventiva de una persona para la investigación de un delito, aspecto regulado en la Legislación Procesal Penal (tanto de 1991 como de 2004);

3. conductas que permiten decretar la privación de libertad como una medida de coerción para garantizar la correcta administración de justicia, aspecto que ha sido regulado, por ejemplo, en el Código Procesal Civil ${ }^{19}$; e

4. intervención con fines de identificación, regulada en el artículo 205 del Código Procesal Penal de $2004^{20}$.

En cualquiera de estas circunstancias, antes de privar a una persona de libertad es necesario evaluar si sus actos se enmarcan dentro de los supuestos de hecho previstos en la ley que habilitan la aplicación de esta medida. Se trata de una labor de subsunción, que le corresponde realizar a la justicia ordinaria — al menos en los tres primeros casos-, en tanto forma parte de las competencias que le han sido asignadas por las respectivas normas procesales.

19 El artículo 53, inciso 2, del Código Procesal Civil autoriza a las autoridades judiciales a «disponer la detención hasta por veinticuatro horas de quien resiste su mandato sin justificación, produciendo agravio a la parte o a la majestad del servicio de justicia». Por otro lado, el proyecto original del Código Procesal Constitucional contemplaba la detención de aquellas autoridades, o particulares, que no cumplieran la sentencia final emitida en los procesos constitucionales de tutela de los derechos fundamentales (amparo, hábeas corpus o hábeas data), propuesta que finalmente no fue aprobada.

20 Código Procesal Penal de 2004, artículo 205: «Control de identidad policial.- 1.- La Policía, en el marco de sus funciones, sin necesidad de orden del Fiscal o del Juez, podrá requerir la identificación de cualquier persona y realizar las comprobaciones pertinentes en la vía pública o en el lugar donde se hubiere hecho el requerimiento, cuando considere que resulta necesario para prevenir un delito u obtener información útil para la averiguación de un hecho punible. [...] 4. En caso no sea posible la exhibición del documento de identidad, según la gravedad del hecho investigado o del ámbito de la operación policial practicada, se conducirá al intervenido a la Dependencia Policial más cercana para exclusivos fines de identificación. Se podrá tomar las huellas digitales del intervenido y constatar si registra alguna requisitoria. Este procedimiento, contado desde el momento de la intervención policial, no puede exceder de cuatro horas, luego de las cuales se le permitirá retirarse».

EL DERECHO FUN-

DAMENTAL A LA

LIBERTAD FÍSICA:

REFLEXIONES

A PARTIR DE LA

CONSTITUCIÓN,

EL CÓDIGO PRO-

CESAL PENAL Y LA

JURISPRUDENCIA

DEL TRIBUNAL

CONSTITUCIONAL 
En esta sección se debe mencionar la prohibición de la prisión por deudas, prevista en la Constitución de $1993^{21}$ y en los textos internacionales sobre derechos humanos ${ }^{22}$. Se trata de un acto que bajo ninguna circunstancia podría ser considerado por la ley como un supuesto que habilite la detención de una persona. En su jurisprudencia, el Tribunal Constitucional ha precisado importantes aspectos con relación a este tema. Así, por ejemplo, ha señalado que la ejecución de la pena efectiva de un fallo condenatorio debido al incumplimiento del pago de la reparación civil no puede considerarse como un acto que vulnera la libertad del sentenciado ni tampoco como violatorio del precepto constitucional sobre la prohibición de la prisión por deudas ${ }^{23}$.

\section{I.2. Procedimiento de privación de la libertad}

Para que una persona sea privada de libertad no basta que su conducta se enmarque dentro de los supuestos de hecho previstos por la ley. Se requiere, también, que exista una orden que autorice su aplicación, salvo en los casos de flagrante delito. Dicha orden, además, debe constar por escrito, encontrase debidamente motivada y ser expedida por una autoridad competente.

\subsubsection{Orden escrita y fundamentada que autorice la privación de libertad} Para que una persona sea privada de libertad se requiere que exista una orden que autorice la aplicación de esta medida. La excepción al respecto se presenta en los casos de detención en flagrante delito.

Toda orden de detención debe constar por escrito y encontrarse debidamente fundamentada, tal como lo exige el artículo 2, inciso 24, literal $\mathrm{f}$ de la Constitución de 1993.

La motivación de las resoluciones judiciales que ordenan la privación de libertad de una persona concuerda asimismo con el artículo 139, inciso 5, de la Constitución, que establece como uno de los principios y derechos de la función jurisdiccional: «La motivación escrita de las resoluciones judiciales en todas las instancias, excepto los decretos de mero trámite, con mención expresa de la ley aplicable y de los fundamentos de hecho en que se sustentan».

Con relación a este tema, el Tribunal Constitucional ha considerado ilegales, inconstitucionales y arbitrarios los mandatos de detención que

21 El artículo 2, inciso 24, literal c de la Constitución de 1993 señala: «No hay prisión por deudas. Este principio no limita el mandato judicial por incumplimiento de deberes alimentarios».

22 En este sentido, el Pacto Internacional de Derechos Civiles y Políticos, artículo 11, establece: «Nadie será encarcelado por el solo hecho de no poder cumplir una obligación contractual", mientras que la Convención Americana sobre Derechos Humanos, artículo 7, inciso 7, señala: «Nadie será detenido por deudas. Este principio no limita los mandatos de autoridad judicial competente dictados por incumplimiento de deberes alimentarios".

23 STC 1316-99-HC, publicada el 29 de mayo de 2000, fundamento 3. 
carecen de motivación, adjetivos que, asimismo, ha extendido a la privación de libertad efectuada al amparo de tales resoluciones ${ }^{24}$.

Es importante señalar, de igual manera, que la orden judicial de detención debe ser mostrada a la persona sobre la que recae esta medida, a efectos de garantizar su derecho de defensa. En este sentido, los incisos 14 y 15 del artículo 139 de la Constitución establecen que «toda persona debe ser informada, inmediatamente y por escrito, de las causas y razones de su detención».

Este derecho también se encuentra reconocido en los instrumentos internacionales sobre derechos humanos. En este sentido, el Pacto Internacional de Derechos Civiles y Políticos (artículo 9, inciso 2) señala que «toda persona detenida será informada, en el momento de su detención, de las razones de la misma [sic], y notificada, sin demora, de la acusación formulada contra ella».

Por su parte, la Convención Americana sobre Derechos Humanos (artículo 7, inciso 4) establece que «toda persona detenida o retenida debe ser informada de las razones de su detención y notificada, sin demora, del cargo o cargos formulados contra ella».

\subsubsection{Orden judicial de privación de libertad expedida por autoridad competente}

Los ordenamientos jurídicos de cada país determinan cuáles son las autoridades que pueden ordenar la privación de libertad de una persona. Por lo general, esta facultad es asignada de forma exclusiva a los jueces. La Constitución peruana de 1993 sigue esta línea y establece, en su artículo 2, inciso 24, literal f, que la privación de libertad de una persona requiere la existencia de un «mandamiento escrito y motivado del juez» ${ }^{25}$.

Sin embargo, las autoridades judiciales solo pueden expedir un orden de detención en el marco de un proceso que sea de su competencia. En caso contrario, cabe la posibilidad de impugnarla.

$\mathrm{Al}$ respecto se puede citar el caso de dos personas que presentaron un hábeas corpus para dejar sin efecto una sentencia judicial que los sancionaba con pena privativa de la libertad por la comisión de un determinado delito. Entre sus argumentos, los demandantes señalaron que el órgano jurisdiccional que expidió la sentencia carecía de competencia para conocer el delito por el cual se les sancionó, lo que afectaba su derecho al juez natural, reconocido en el artículo 139, inciso 3, de la

EL DERECHO FUN-

DAMENTAL A LA

LIBERTAD FÍSICA:

REFLEXIONES

A PARTIR DE LA

CONSTITUCIÓN,

EL CÓDIGO PRO-

CESAL PENAL Y LA

JURISPRUDENCIA

DEL TRIBUNAL

CONSTITUCIONAL 
Constitución ${ }^{26}$. En su decisión, el Tribunal Constitucional declaró fundado el hábeas corpus, ya que se constató la alegada falta de competencia de la autoridad judicial, y luego ordenó la inmediata excarcelación de las personas sentenciadas ${ }^{27}$.

Asimismo, el Tribunal Constitucional ha tenido oportunidad de pronunciarse respecto de las órdenes de detención expedidas por la justicia militar contra personas sobre las cuales no tenía competencia alguna de someter a un proceso penal, como es el caso de los militares que han pasado a la situación de retiro. En estas situaciones, el tribunal ha ordenado la suspensión de los procesos seguidos contra estas personas ante la justicia militar ${ }^{28}$.

En relación con este tema, es importante precisar que, para el Tribunal Constitucional, la privación de libertad de una persona ordenada por una autoridad judicial que carece de competencia para dictar una medida de este tipo, no supone que las conductas delictivas que se le imputan a esa persona desaparecen, sino que las mismas deberán juzgarse por las instancias judiciales competentes, que podrán ordenar su detención si así lo consideran necesario ${ }^{29}$.

\section{PROHIBICIÓN DE DETENCIONES ARBITRARIAS} Hemos señalado que una de las garantías de la libertad física es la prohibición de detenciones ilegales, entendidas como aquellas que se producen al margen de los supuestos de hecho previstos legalmente para que proceda la privación de libertad de una persona. Así como los procedimientos que no se respetan.

Pero existen, además, restricciones a la libertad física que, a pesar de su conformidad con las normas legales, se encuentran prohibidas. Por esta razón, las normas internacionales sobre derechos humanos no solo prohíben toda privación de la libertad que se realice sin la observación de las condiciones legales previstas para tal efecto, sino también cualquier restricción a este derecho fundamental que resulte arbitraria.

En este sentido, la Declaración Universal de Derechos Humanos (artículo 9) establece que «nadie podrá ser arbitrariamente detenido, preso ni desterrado». Por su parte, el Pacto Internacional de Derechos Civiles y Políticos (artículo 9, inciso 1) dispone que «nadie podrá ser sometido a detención o prisión arbitrarias». Asimismo, la Convención Americana

26 Esta norma constitucional dispone: «Son principios y derechos de la función jurisdiccional: La observancia del debido proceso y la tutela jurisdiccional. Ninguna persona puede ser desviada de la jurisdicción predeterminada por la ley, ni sometida a procedimiento distinto de los previamente establecidos, ni juzgada por órganos jurisdiccionales de excepción ni por comisiones especiales creadas al efecto, cualquiera sea su denominación».

27 STC 942-96-HC, publicada el 20 de agosto de 1997.

28 STC 1131-99-HC, publicada el 15 de enero de 2000. Sobre el mismo tema puede también verse la STC 585-96-HC, publicada el 30 de septiembre de 1998.

29 STC 678-99-HC, publicada el 16 de febrero de 2000. 
sobre Derechos Humanos (artículo 7, inciso 3) precisa que «nadie puede ser sometido a detención o encarcelamiento arbitrarios».

Al precisar los alcances de una privación arbitraria de la libertad, la Corte Interamericana de Derechos Humanos ha señalado que «nadie puede ser sometido a detención o encarcelamiento por causas y métodos que - aun calificados de legales- puedan reputarse como incompatibles con el respeto a los derechos fundamentales del individuo por ser, entre otras cosas, irrazonables, imprevisibles, o faltos de proporcionalidad ${ }^{30}$.

En consecuencia, corresponde a los operadores jurídicos no solo identificar si una privación de la libertad se ha dictado conforme a lo previsto en una determinada norma legal, sino también evaluar si esta es compatible con el ejercicio de los derechos fundamentales y los principios constitucionales.

A modo de ejemplo, podemos citar el caso de lo ocurrido en el Perú con la legislación antiterrorista. En 2003 el Tribunal Constitucional declaró como inconstitucional el denominado delito de traición a la patria regulado mediante el decreto ley 25659, por considerar —entre otras razones - que esta norma afectaba el principio de legalidad, ya que su contenido implicaba una reiteración de lo previsto en el tipo penal de terrorismo. Al respecto, señaló ${ }^{31}$ :

[...] si la totalidad de los supuestos de hecho descritos en el tipo penal de traición a la patria se asimilan a las modalidades de terrorismo preexistentes; hay, pues, duplicación del mismo contenido. En esencia, el legislador sólo ha reiterado el contenido del delito de terrorismo en el tipo relativo al de traición a la patria, posibilitando con ello que un mismo hecho pueda indistintamente ser subsumido en cualquiera de los tipos penales y que, en su caso, con la elección del tipo penal aplicable, su juzgamiento pueda ser realizado, alternativamente, por los tribunales militares o por la jurisdicción ordinaria.

A juicio del Tribunal Constitucional, ello afecta el principio de legalidad penal, ya que da lugar a un inaceptable grado de discrecionalidad del Ministerio Público y las autoridades judiciales, quienes podrían subsumir la comisión de un mismo delito en distintos tipos penales.

En este sentido, una sanción impuesta por la comisión del delito de traición a la patria bien podría haber sido considerada - mientras estuvo vigente- como una privación de la libertad efectuada conforme a lo dispuesto en una norma legal (el decreto ley 25659), pero que resultaba arbitraria, por las razones expuestas por el tribunal, en tanto afectaba el principio de legalidad.

30 Corte Interamericana de Derechos Humanos. Caso Gangaram Panday, sentencia del 21 de enero de 1994, parágrafo 47, y Caso Cesti, sentencia del 29 de setiembre de 1999, parágrafo 140.

31 STC 10-2002-Al/TC, publicada el 4 de enero de 2003 en el diario oficial El Peruano, fundamentos 38 y 39 .

EL DERECHO FUN-

DAMENTAL A LA

LIBERTAD FÍSICA:

REFLEXIONES

A PARTIR DE LA

CONSTITUCIÓN,

EL CÓDIGO PRO-

CESAL PENAL Y LA

JURISPRUDENCIA

DEL TRIBUNAL

CONSTITUCIONAL 
Por su parte, la Constitución de 1993 no establece de forma expresa la prohibición de detenciones arbitrarias. Pero, en el artículo 139, inciso 7, se refiere a ella de forma indirecta a fin de señalar que toda persona tiene derecho a una «indemnización por detención arbitraria, en la forma que determine la ley y sin perjuicio de la responsabilidad a que hubiere lugar».

Por ello, una lectura de los tratados de derechos humanos, en forma conjunta con la jurisprudencia del Tribunal Constitucional, permite una cabal comprensión de esta garantía del derecho fundamental a la libertad física.

\section{DERECHO AL TRASLADO INMEDIATO ANTE UNA AUTORIDAD JUDICIAL}

Toda persona privada de libertad — sea porque existe una orden judicial que así lo dispone o por haber sido encontrada en situación de flagrante delito- tiene derecho a ser trasladada inmediatamente ante una autoridad judicial. Este derecho se encuentra reconocido de la siguiente manera en la Constitución de 1993 (artículo 2, inciso 24, literal f):

El detenido debe ser puesto a disposición del juzgado correspondiente, dentro de las veinticuatro horas o en el término de la distancia. Estos plazos no se aplican a los casos de terrorismo, espionaje y tráfico ilícito de drogas. En tales casos, las autoridades policiales pueden efectuar la detención preventiva de los presuntos implicados por un término no mayor de quince días naturales. Deben dar cuenta al Ministerio Público y al Juez, quien puede asumir jurisdicción antes de vencido dicho término.

Los instrumentos internacionales sobre derechos humanos también se pronuncian en relación a este tema. En este sentido, el Pacto Internacional de Derechos Civiles y Políticos (artículo 9, inciso 3) establece: «Toda persona detenida o presa a causa de una infracción penal será llevada sin demora ante un juez u otro funcionario autorizado por la ley para ejercer funciones judiciales [...]» (subrayado nuestro).

Por su parte, la Convención Americana sobre Derechos Humanos (artículo 7, inciso 5) señala, en similar redacción: «Toda persona detenida o retenida debe ser llevada, sin demora, ante un juez u otro funcionario autorizado por la ley para ejercer funciones judiciales [...]» (subrayado nuestro).

De la lectura del texto constitucional y las normas internacionales sobre derechos humanos, se deducen dos derechos de especial importancia: primero, el derecho de toda persona privada de libertad a ser trasladada ante una autoridad judicial, y segundo, el derecho a que ese traslado se realice sin demora. 


\section{III.1. Derecho de toda persona privada de libertad a ser trasladada ante una autoridad judicial}

Respecto a este derecho, corresponde identificar cuál es la finalidad del traslado ante una autoridad judicial, lo cual varía según la situación en la que se produce la detención ${ }^{32}$.

Si la privación de la libertad se ha dado como consecuencia de una resolución judicial, se presume que la expedición de esta ha estado precedida de un análisis sobre los hechos que justifican la medida restrictiva de la libertad física. Este razonamiento, además, debe constar en la respectiva resolución, que debe ser motivada. En tales circunstancias, la autoridad judicial ha evaluado de forma previa el caso concreto puesto a su conocimiento, por lo que el traslado de la persona detenida implica ponerla bajo la competencia de la autoridad judicial para el desarrollo del respectivo proceso penal.

Pero el tema se presenta más complejo en los casos de flagrante delito, donde son las autoridades policiales las que - en un primer momentoidentifican y califican un hecho como tal. En tales casos, las autoridades judiciales deben evaluar si efectivamente se ha producido un delito en situación de flagrancia y, a partir de los elementos existentes hasta ese momento sobre la comisión del mismo, tomar una decisión sobre si la persona privada de libertad debe mantenerse en tal situación.

Para tal efecto, el juez contará, básicamente, con la información que le sea proporcionada por la Policía, aspecto vinculado con el siempre polémico tema de la duración del tiempo del traslado del detenido ante la autoridad judicial.

\section{III.2. Derecho a que el traslado ante la autoridad judicial se realice sin demora}

Los instrumentos internacionales sobre derechos humanos señalan que toda persona privada de libertad debe ser llevada, sin demora, ante una autoridad judicial. Sobre este punto, la Corte Interamericana de Derechos Humanos ha señalado ${ }^{33}$ :

El artículo 7.5 de la Convención (Americana) dispone, en su parte inicial, que la detención de una persona debe ser sometida sin demora a revisión judicial. La Corte ha determinado que el control judicial sin demora es una medida tendiente a evitar la arbitrariedad o ilegalidad de las detenciones, tomando en cuenta que en un Estado de Derecho corresponde al juzgador garantizar los derechos del detenido, autorizar

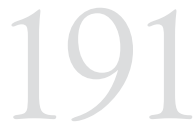

EL DERECHO FUNDAMENTAL A LA LIBERTAD FÍSICA: REFLEXIONES A PARTIR DE LA CONSTITUCIÓN, EL CÓDIGO PROCESAL PENAL Y LA JURISPRUDENCIA DEL TRIBUNAL CONSTITUCIONAL

32 Es importante precisar que si bien los instrumentos internacionales sobre derechos humanos establecen la posibilidad de que la persona detenida sea trasladada ante una autoridad judicial $u$ «otro funcionario autorizado por la ley para ejercer funciones judiciales», la Constitución de 1993 solo admite como válida la primera opción.

33 Corte Interamericana de Derechos Humanos. Caso Bayarri Vs. Argentina. Excepción Preliminar, Fondo, Reparaciones y Costas. Sentencia del 30 de octubre de 2008, parágrafo 65. 
la adopción de medidas cautelares o de coerción, cuando sea estrictamente necesario, y procurar, en general, que se trate al inculpado de manera consecuente con la presunción de inocencia.[...] La Corte ha reiterado que el juez debe oír personalmente al detenido y valorar todas las explicaciones que éste le proporcione, para decidir si procede la liberación o el mantenimiento de la privación de libertad. Lo contrario equivaldría a despojar de toda efectividad el control judicial dispuesto en el artículo 7.5 de la Convención.

Las normas internacionales no fijan un plazo máximo para dicho traslado, que corresponde ser precisado en las normas legales de cada país — especialmente en las normas de índole procesal penal-, pero siempre respetando la idea central de esta garantía: que el traslado se realice sin demora para que una autoridad judicial evalúe la legalidad de la detención.

En el caso peruano, los plazos sobre el traslado de una persona privada de libertad ante la autoridad judicial han sido establecidos a nivel constitucional. Esta opción demuestra la importancia de la materia; el constituyente ha deseado incluir en la máxima norma del ordenamiento jurídico un aspecto que bien podría ser establecido en una norma infraconstitucional, seguramente para evitar el establecimiento de plazos imprecisos o demasiado extensos a través de las leyes.

Sin embargo, una modificación de tales plazos, en la perspectiva de atender las exigencias de la realidad, resulta sumamente compleja, debido a los procedimientos para que se produzca una reforma constitucional.

La Constitución de 1993 (artículo 2, inciso 24, literal f) establece dos tipos de plazos. Como regla general, señala que toda persona privada de libertad en virtud de una orden judicial o flagrante delito debe ser puesta «a disposición del juzgado correspondiente, dentro de las veinticuatro horas o en el término de la distancia».

$\mathrm{Al}$ respecto, el Tribunal Constitucional ha señalado que el vencimiento del plazo de venticuatro horas sin que la persona detenida sea puesta a disposición de la autoridad judicial, convierte la detención en «arbitraria e indebida ${ }^{34}$.

Así, por ejemplo, en el caso de una persona detenida al momento de oponerse a un desalojo judicial, el tribunal señaló que, si bien se había acreditado que la detención cuestionada se produjo en situación de flagrante delito al haberse impedido una diligencia judicial de lanzamiento, dicha detención se convirtió en arbitraria cuando el detenido permaneció privado de libertad algunas horas más de lo permitido constitucionalmente ${ }^{35}$. 
En términos generales, la línea jurisprudencial del Tribunal Constitucional sobre este tema ha sido la siguiente ${ }^{36}$ :

[...] aun cuando una persona ha sido detenida de conformidad con la Constitución por mérito de una orden judicial o ante flagrante delito, dicha detención resulta arbitraria si es que no se pone al detenido a disposición del juzgado correspondiente en los plazos expuestos en ella [...]; debiéndose resaltar, además, que dichos plazos establecen términos máximos que exigen por parte de las autoridades policiales la máxima diligencia de que dicho acto se efectúe tan inmediatamente como sea posible, vale decir, en el lapso razonablemente indispensable dentro del plazo máximo que la norma constitucional establece.

Esta línea interpretativa del Tribunal Constitucional se ha mantenido a lo largo de los años. Incluso, en el año 2010, le dio carácter de precedente vinculante a propósito de un caso bastante singular, donde la demora en el traslado de una persona detenida presentó diversas dificultades por el retraso en la entrega de viáticos a los policías para que puedan proceder con dicha diligencia. En este fallo, el tribunal precisó ${ }^{37}$ :

Resulta lesiva al derecho personal a la libertad personal la privación de ésta en los supuestos en que ha transcurrido el plazo máximo para la detención, o cuando, estando dentro de dicho plazo, se ha rebasado el plazo estrictamente necesario; en ambos casos, dicho estado de cosas queda privado de fundamento constitucional, y la consecuencia debe ser la puesta inmediata de la persona detenida a disposición del juez competente para que sea éste quien determine si procede la detención judicial respectiva o la libertad de la persona, sin perjuicio de las responsabilidades que señala la ley para la autoridad, funcionario o persona que hubiera incurrido en ellas.

Como una excepción al plazo de venticuatro horas, la Constitución de 1993 establece que respecto de los delitos de terrorismo, espionaje y tráfico ilícito de drogas, el plazo de traslado al juzgado correspondiente puede durar como máximo quince días. Esta excepción alude únicamente al plazo, ya que los motivos de la detención solo pueden ser la orden judicial o el flagrante delito.

El incumplimiento del plazo de quince días establecido para estos delitos también convierte en arbitraria la detención. Por ejemplo, en una oportunidad el Tribunal Constitucional tomó conocimiento del caso de una persona detenida gracias a una orden judicial emitida por la presunta comisión del delito de tráfico ilícito de drogas. Esta persona, sin embargo, estuvo detenida más de sesenta días sin haber sido puesta a disposición de las autoridades judiciales competentes a fin de que se defina su situación jurídica.

EL DERECHO FUNDAMENTAL A LA LIBERTAD FÍSICA: REFLEXIONES A PARTIR DE LA CONSTITUCIÓN, EL CÓDIGO PROCESAL PENAL Y LA JURISPRUDENCIA DEL TRIBUNAL CONSTITUCIONAL 
En su decisión, el tribunal consideró afectadas no solo las disposiciones constitucionales sobre la materia, sino también las normas antes mencionadas del Pacto Internacional de Derechos Civiles y Políticos (artículo 9, inciso 3) y la Convención Americana sobre Derechos Humanos (artículo 7, inciso 5) ${ }^{38}$.

Es interesante plantear como hipótesis de trabajo si realmente se justifica que la Constitución establezca dos plazos distintos para el traslado de una persona ante las autoridades judiciales. Incluso, si el término de quince días previsto en la Constitución para determinados delitos es compatible con la exigencia de las normas internacionales sobre derechos humanos, que ordenan que dicho traslado se realice sin demora.

En estos casos, el texto constitucional dispone la obligación de que la detención sea puesta en conocimiento del Ministerio Público o el juzgado respectivo, quienes pueden asumir jurisdicción antes de vencido dicho plazo, Consideramos, sin embargo, que tal obligación no satisface las inquietudes planteadas.

Una justificación para establecer dos plazos distintos para el traslado de un detenido ante una autoridad judicial podría ser la complejidad de delitos como el terrorismo, el espionaje y el tráfico ilícito de drogas que, por lo general, son cometidos por organizaciones criminales. Sin embargo, si esa justificación fuera válida, se podría argumentar que debería aumentar la lista de delitos en los que el traslado pueda demorar hasta quince días, de modo tal que la excepción sea aplicada a todos los casos en los que se produzca un hecho delictivo cometido por una organización criminal ${ }^{39}$. Por ello, nos inclinamos a considerar que no existe una justificación válida para establecer un plazo diferente al de las venticuatro horas.

Pero más difícil es compatibilizar el plazo de quince días para el traslado ante una autoridad judicial con lo dispuesto por los tratados sobre derechos humanos, que señalan que el mismo debe realizarse sin demora. Al interpretar los alcances de la Convención Americana sobre Derechos Humanos, la Comisión Interamericana ha sugerido que «no se considerará razonable una demora de más de dos o tres días en llevar al detenido ante una autoridad judicial en general ${ }^{40}$.

38 STC 1273-HC, publicada el 29 de marzo de 2001.

39 Esta ha sido, por ejemplo, la fundamentación principal de diversos proyectos de reforma constitucional presentados en el Congreso de la República el período legislativo 2006-2011, que fueron debatidos por la Comisión de Constitución y Reglamento en su Sesión del 16 de marzo de 2010, pero que quedaron en un cuarto intermedio. Nos referimos a los proyectos 1155/2006-CR, 1320/2006-CR y 1424/2006-CR. Con el primero se proponía modificar el literal f, del numeral 24, del artículo 2 de la Constitución Política del Estado, ampliando el plazo de detención hasta por quince días y sin que exista flagrancia para los casos de violación sexual. Mediante el segundo se proponía modificar el literal f, del numeral 24, del artículo 2 de la Constitución, que ampliaba el plazo de detención hasta por quince días para los delitos de secuestro y robo agravado. Finalmente, la tercera propuesta planteaba ampliar el plazo de detención hasta por quince días para los delitos de secuestro y extorsión.

40 Comisión Interamericana de Derechos Humanos. Informe sobre Terrorismo y Derechos Humanos. $\mathrm{CIDH}, 2002$, parágrafo 122. 
En nuestra opinión, esta incompatibilidad entre la Constitución y los tratados sobre derechos humanos debe ser resuelta considerando aquello que resulte más favorable para el ejercicio de los derechos fundamentales. Es decir, la norma que sea menos restrictiva de las garantías de la libertad física, que en este supuesto sería la de los tratados.

\section{CARÁCTER EXCEPCIONAL DE LA DETENCIÓN JUDICIAL}

En el transcurso de un proceso penal, las autoridades judiciales se encuentran facultadas para expedir una orden de detención contra los presuntos responsables de la comisión de un delito.

Este tipo de medida se caracteriza por ser provisional, puesto que solo debe durar lo estrictamente necesario para lograr los objetivos que justifican su expedición y debe cesar tan pronto como hayan desaparecido estas causas. Además, debe ser una medida motivada, pues solo puede ser aplicada si existe la necesidad de mantener detenida a una persona presuntamente implicada en la comisión de un delito, a fin de facilitar la investigación respectiva.

Asimismo, debe ser una medida excepcional, característica que se encuentra remarcada en el Pacto Internacional de Derechos Civiles y Políticos (artículo 9, inciso 3), el cual establece:

La prisión preventiva de las personas que hayan de ser juzgadas no debe ser la regla general, pero su libertad podrá estar subordinada a garantías que aseguren la comparecencia del acusado en el acto del juicio, o en cualquier momento de las diligencias procesales y, en su caso, para la ejecución del fallo (subrayado nuestro).

Si bien la Convención Americana sobre Derechos Humanos no establece una disposición similar a la del Pacto Internacional, la Corte Interamericana de Derechos Humanos ha tenido oportunidad de señalar que - como consecuencia de la necesidad de respetar el derecho a la presunción de inocencia- « se deriva la obligación estatal de no restringir la libertad del detenido más allá de los límites estrictamente necesarios para asegurar que no impedirá el desarrollo eficiente de las investigaciones y que no eludirá la acción de la justicia, pues la prisión preventiva es una medida cautelar, no punitiva ${ }^{41}$.

Este criterio, como se verá más adelante, fue empleado por la Corte para decidir sobre un caso acerca de la excesiva duración de un proceso penal, pero lo consideramos también válido para justificar el carácter excepcional de las detenciones judiciales expedidas en el marco de un proceso penal.

41 Comisión Interamericana de Derechos Humanos. Caso Suárez Rosero, sentencia del 12 de noviembre de 1997, parágrafo 77 . 
La Constitución de 1993 no contiene disposición alguna en relación a este tema, pero el Tribunal Constitucional ha tenido oportunidad de establecer la siguiente línea jurisprudencial ${ }^{42}$ :

[...] una interpretación coherente de la Constitución Política del Estado de conformidad con los tratados y acuerdos internacionales, permite afirmar que la detención judicial en tanto importa la limitación más intensa del derecho fundamental a la libertad personal, sólo debe aplicarse excepcionalmente y bajo determinadas circunstancias legalmente configuradas (subrayado nuestro).

Las normas que regulan el proceso penal establecen los requisitos para que pueda ordenarse la detención judicial de una persona. En este sentido, el Código Procesal Penal de 1991 (artículo 135, actualmente vigente) señala que dicha medida solo puede expedirse si se cumplen —de forma conjunta — los siguientes requisitos:

- que existan suficientes elementos probatorios de la comisión de un delito doloso que vincule al imputado como autor o partícipe de aquel;

- que la sanción a imponerse sea superior a un año de pena privativa de libertad (criterio de la gravedad de la pena ${ }^{43}$; y

- que el imputado, en razón a sus antecedentes y otras circunstancias, tratase de eludir la acción de la justicia o perturbar la actividad probatoria (criterio del peligro procesal).

Similares criterios han sido establecidos en el artículo 268, inciso 1, del Código Procesal Penal de 2004. En el caso del inciso 2 del mismo artículo, se establecen nuevos presupuestos a tomar en cuenta para que proceda una detención judicial preventiva. La citada norma señala:

1. El Juez, a solicitud del Ministerio Público, podrá dictar mandato de prisión preventiva, si atendiendo a los primeros recaudos sea posible determinar la concurrencia de los siguientes presupuestos:

a) Que existen fundados y graves elementos de convicción para estimar razonablemente la comisión de un delito que vincule al imputado como autor o partícipe del mismo.

b) Que la sanción a imponerse sea superior a cuatro años de pena privativa de libertad; $y$

c) Que el imputado, en razón a sus antecedentes y otras circunstancias del caso particular, permita colegir razonablemente que tratará de debía ser mayor a cuatro años. Mediante la ley 28726, publicada el 9 de mayo de 2006, se estableció que solo fuera mayor a un año. Posteriormente, mediante la ley 29499, publicada el 19 de enero de 2010 , se volvió a modificar el texto del artículo 135, y se retornó al texto original sobre la materia. Sin embargo, esta ley se encuentra condicionada a una aplicación progresiva, ya que el tema de fondo de la norma está relacionada con la implementación de la denominada vigilancia electrónica. 
eludir la acción de la justicia (peligro de fuga) u obstaculizar la averiguación de la verdad (peligro de obstaculización).

2. También será presupuesto material para dictar mandato de prisión preventiva, sin perjuicio de la concurrencia de los presupuestos establecidos en los literales a) y b) del numeral anterior, la existencia de razonables elementos de convicción acerca de la pertenencia del imputado a una organización delictiva o su reintegración a la misma, y sea del caso advertir que podrá utilizar los medios que ella le brinde para facilitar su fuga o la de otros imputados o para obstaculizar la averiguación de la verdad.

Un tema que merece especial atención es la forma en que el Tribunal Constitucional ha resuelto las demandas de hábeas corpus presentadas contra resoluciones judiciales que ordenan una detención judicial preventiva. En nuestra opinión, en estos casos corresponde que el tribunal se pronuncie únicamente sobre si existió una motivación para la decisión judicial, mas no sobre si se cumplieron los requisitos mencionados en la legislación procesal penal, ya que son los jueces especializados en lo penal los que cuentan con mayores elementos para identificar si existe un peligro de fuga o si existen suficientes elementos probatorios de la comisión de un delito por parte de una persona. En caso contrario, el tribunal se convertiría en una instancia de apelación de este tipo de resoluciones, lo que escapa a su competencia.

La tendencia general del tribunal ha sido declarar improcedentes este tipo de demandas, salvo en aquellos casos donde ha identificado una flagrante afectación de derechos fundamentales. Así, por ejemplo, en una oportunidad el tribunal señalót

[la resolución judicial] que implicó una severa restricción a la libertad del beneficiario y que se fundamentó en la supuesta gravedad del delito que se le imputa y la existencia de peligro procesal por una probable fuga, no configura una motivación resolutoria suficiente que sustente la necesidad de la continuación de encarcelamiento preventivo del beneficiario, por cuanto los elementos del juicio que obran en autos referidos a su situación jurídico penal no justifican que sea pasible del rigor de esta medida de coerción [...].

En otra oportunidad, el Tribunal Constitucional evaluó el requisito del peligro procesal respecto de la orden de detención expedida contra una persona a quien se le seguía un proceso penal por el delito de tráfico ilícito de drogas. En sus argumentos, señaló ${ }^{45}$ :

[...] la imposición de esta severa medida cautelar no se condice con las antedichas circunstancias procesales favorables que se desprenden de su situación jurídico penal, y a mayor argumento, con el derecho

EL DERECHO FUNDAMENTAL A LA LIBERTAD FÍSICA: REFLEXIONES A PARTIR DE LA CONSTITUCIÓN, EL CÓDIGO PRO-

CESAL PENAL Y LA JURISPRUDENCIA DEL TRIBUNAL CONSTITUCIONAL 
constitucional de presunción de inocencia que le asiste como procesado, y que determina que el grado de exigencia cautelar siempre debe ser el menos gravoso y aflictivo para el procesado, más aún, si en el caso del beneficiario no se aprecian elementos de juicio que permitan apreciar la existencia de peligro procesal, resultando por ello arbitraria la continuación de su encarcelamiento preventivo procesal.

En ambos casos, el tribunal dispuso la inmediata libertad de los detenidos y precisó que, con estas decisiones, no se arrogaba competencias que no le están permitidas. Tampoco que puedieran significar un pronunciamiento en torno al fondo del proceso penal que se le seguía a las personas que estaban privadas de libertad en virtud de una orden de detención judicial, pues ese pronunciamiento es competencia de los jueces de la vía ordinaria.

\section{DERECHO AL PLAZO RAZONABLE DE LA DETENCIÓN JUDICIAL PREVENTIVA}

\section{V.1. Reconocimiento como contenido implícito de la li- bertad individual}

Los instrumentos internacionales sobre derechos humanos reconocen el derecho de toda persona acusada de un delito a ser juzgada dentro de plazos razonables. En el marco de los procesos penales si se emite una orden judicial de detención, pero estos se prolongan de forma excesiva, la detención no debería durar lo mismo, ya que cuenta con fundamentos propios (como evitar el peligro de fuga o la perturbación de la investigación).

En este sentido, si la duración de la medida privativa de libertad no es razonable, la persona con orden de detención tiene derecho a recuperar su libertad, sin perjuicio de que el proceso en su contra continúe ${ }^{46}$. A esta garantía se la conoce como el Derecho al Plazo Razonable de Duración de la Detención Judicial Preventiva.

Así, el Pacto Internacional de Derechos Civiles y Políticos (artículo 9, inciso 3) señala: «Toda persona detenida o presa a causa de una infracción penal $[\ldots]$ tendrá derecho a ser juzgada dentro de un plazo razonable o a ser puesta en libertad».

Por su parte, la Convención Americana sobre Derechos Humanos (artículo 7, inciso 5) dispone: «Toda persona detenida o retenida [...] tendrá derecho a ser juzgada dentro de un plazo razonable o a ser puesta en libertad, sin perjuicio de que continúe el proceso. Su libertad podrá estar condicionada a garantías que aseguren su comparecencia en el juicio». 
La Constitución de 1993 no reconoce de modo expreso este derecho. Pero el Tribunal Constitucional lo ha reconocido como parte integrante del contenido de la libertad física, y ha concordado para tal efecto las normas constitucionales sobre debido proceso y dignidad de la persona con las normas internacionales antes mencionadas ${ }^{47}$.

Así, se ha pronunciado a partir de casos donde, a pesar de haberse vencido el plazo máximo de detención judicial previsto en la legislación procesal penal, las personas procesadas continuaban detenidas. Los argumentos principales del tribunal en estos casos pueden ser resumidos de la siguiente manera ${ }^{48}$ :

- Una forma de detención arbitraria por parte de una autoridad o funcionario es omitir el cumplimiento obligatorio de normas procesales que disponen la libertad inmediata de un detenido, como el caso del beneficio procesal de excarcelación por exceso de detención, previsto en el artículo 137 del Código Procesal Penal.

- La medida cautelar de detención no debe durar más del tiempo que sea necesario para el logro de los fines de la investigación y deberá ser aplicada con humanidad y respeto por la dignidad del ser humano ${ }^{49}$.

- Si la detención pudiera mantenerse todo el tiempo que dura el proceso — - sin adolecer de dilación indebida—, dicha situación contravendría el adecuado ejercicio de la potestad judicial coercitiva que tiene como fundamentos y límites el derecho a la presunción de inocencia que le asiste al procesado, tal como lo reconoce el artículo 2, inciso 24, literal e, de la Constitución, y a que su proceso se desarrolle en un plazo considerado razonable.

- La excarcelación constituye una legítima pretensión constitucionalmente garantizada.

En estos casos, el derecho internacional de los derechos humanos ha servido de fundamento para que el Tribunal Constitucional reconozca el derecho al plazo razonable de duración de la detención judicial preventiva como contenido implícito de la libertad física.

A fin de garantizar este derecho, las normas legales suelen establecer plazos máximos de detención judicial preventiva. En el caso peruano, estos plazos se encuentran previstos en el artículo 137, primer párrafo, del Código Procesal Penal de 1991, actualmente vigente.

Respecto a estos plazos, el Tribunal Constitucional se ha pronunciado — como veremos más adelante- para señalar principalmente que el

EL DERECHO FUN-

DAMENTAL A LA

LIBERTAD FÍSICA:

REFLEXIONES

A PARTIR DE LA

CONSTITUCIÓN,

EL CÓDIGO PRO-

CESAL PENAL Y LA

JURISPRUDENCIA

DEL TRIBUNAL

CONSTITUCIONAL 
vencimiento de los mismos sin que se produzca la excarcelación del imputado constituye un acto lesivo de la libertad física.

\section{V.2. Criterios para evaluar el plazo razonable de duración de la detención judicial preventiva}

Para el análisis de este tema, el Tribunal Constitucional también ha acudido al derecho internacional, a fin de establecer criterios que permitan a los jueces y tribunales determinar — en cada caso concreto— cuándo se está ante una situación donde se ha respetado o inobservado el plazo razonable de detención preventiva. Estos criterios son similares a los previstos en la doctrina y la jurisprudencia internacional y comparada respecto del plazo razonable de duración de un proceso, pero aplicados al supuesto de las detenciones judiciales. Tales criterios son ${ }^{50}$ :

- Actuación de los órganos judiciales. De acuerdo a este criterio, se debe evaluar si las autoridades judiciales actuaron con la diligencia debida en la tramitación del proceso penal en el marco del cual se ha dictado una orden de detención judicial preventiva.

- Complejidad del asunto. De acuerdo a este criterio, se debe evaluar el tipo de controversia ante el que se está presente. No es lo mismo evaluar el plazo de detención judicial en un proceso seguido contra una persona que en un proceso donde se investiga una organización criminal de narcotráfico o corrupción.

- Actividad procesal del detenido. Un proceso judicial puede demorarse como consecuencia de la conducta del procesado o de actos procesales realizados por su defensa, aspectos que también deben ser evaluados.

Estos tres criterios permiten evaluar —en cada caso concreto- si el plazo de duración de la detención judicial preventiva es razonable. A la vez, la legislación procesal penal establece unos plazos máximos que no pueden ser excedidos. El tribunal ha equiparado ambos plazos (el plazo razonable y el plazo legal), a pesar de ser distintos.

\section{V.3. Problemas con el plazo máximo de detención judicial preventiva previsto legalmente}

Si bien el Tribunal Constitucional peruano ha establecido que una persona no puede ser privada en forma preventiva de su libertad más allá del plazo máximo previsto legalmente, han surgido dudas sobre cuál es

50 Estos criterios fueron desarrollados por el tribunal en la STC 2915-2004-HC (caso Federico Berrocal Prudencio), publicada el 25 de noviembre de 2004, fundamentos 18-31. Se trata de la decisión más importante de este órgano sobre el plazo de la detención judicial preventiva, cuyos lineamientos se mantienen vigentes hasta la actualidad. De forma complementaria debe ser revisada la STC 37712004-HC (caso Miguel Sánchez Calderón), publicada el 2 de febrero de 2005, la que fue calificada por el tribunal como precedente vinculante al amparo de lo dispuesto en el artículo VII del Título Preliminar del Código Procesal Constitucional. 
este plazo. Se trata de un tema de permanente discusión en el Perú, como consecuencia de la excarcelación de varias personas procesadas por graves delitos, como tráfico ilícito de drogas, corrupción, etcétera.

Existía una jurisprudencia del tribunal sobre los plazos máximos de detención judicial preventiva autorizados por la ley que fue interpretada de diferentes formas. En una decisión emitida a finales de 2004, sin embargo, se precisaron los alcances de la misma; aunque no dejaron de ser polémicos.

En términos generales, el tribunal ha señalado que de conformidad con el artículo 137 del Código Procesal Penal existen tres plazos máximos de detención. Los dos primeros, de nueve (9) y dieciocho (18) meses, se refieren a casos que no son complejos y se diferencian por el tipo de proceso en que se tramitan las causas (procedimiento ordinario y especial, respectivamente). El tercero, de acuerdo a la complejidad del caso y el número de procesados y agraviados, puede ser de hasta treinta y seis (36) meses.

Asimismo, de acuerdo al segundo párrafo del mismo artículo 137, estos tres plazos pueden ser duplicados, a dieciocho (18), treinta y seis (36) y hasta setenta y dos (72) meses, respectivamente. En el caso de las dos primeras prórrogas, deberán evaluarse los mismos criterios que para dictar la orden judicial de detención (actuación de los órganos judiciales, complejidad del asunto y actividad del procesado). En el caso de la tercera prórroga, únicamente será posible si la demora en el desarrollo del proceso se debe al imputado ${ }^{51}$.

Sin embargo, el tribunal no ha evaluado si los plazos máximos legales y la duración máxima de las prórrogas son compatibles con el derecho al plazo razonable de duración de la detención judicial preventiva. En consecuencia, una persona puede estar privada de libertad en el Perú hasta tres años (36 meses) o seis años (72 meses) sin que exista una sentencia sobre su inocencia o culpabilidad respecto de la comisión de determinado delito.

La compatibilidad con la Constitución del plazo de detención judicial preventiva establecido a nivel legal constituye un tema polémico y delicado. El texto del artículo 137 del Código Procesal Penal ha sido validado por el tribunal. Si hubiese existido un mayor análisis —en abstracto - sobre su contenido, quizás hubiese ponderado con mayor

51 Con posterioridad, el Tribunal Constitucional señaló que en el caso específico del tráfico ilícito de drogas, el plazo de detención judicial preventiva mayor a treinta y seis (36) meses podía estar justificado en atención a las particularidades en que se cometió este delito. En este sentido, en la STC 7624-2005-HC (caso Hernán Buitrón Rodríguez), publicada el 2 de agosto de 2006, señaló: «Cuando en casos excepcionalísimos, el delito de tráfico ilícito de drogas represente un grave peligro para la seguridad ciudadana, la soberanía nacional, el estado de derecho y de la sociedad en conjunto, el juez podrá disponer la prolongación del plazo de detención más allá de 36 meses hasta el máximo permitido por ley, mediante resolución debidamente motivada».

EL DERECHO FUNDAMENTAL A LA LIBERTAD FÍSICA: REFLEXIONES A PARTIR DE LA CONSTITUCIÓN, EL CÓDIGO PROCESAL PENAL Y LA JURISPRUDENCIA DEL TRIBUNAL CONSTITUCIONAL 
profundidad la relación entre los plazos máximos legales —incluidas las prórrogas- y el derecho al plazo razonable de detención preventiva.

Tal vez, a partir de dicho análisis, el tribunal se hubiese pronunciado en sentido contrario. Es decir, hubiera manifestado que algunos plazos que autoriza el artículo 137 son incompatibles con la libertad física. Así, hubiera exhoratdo al Congreso a establecer plazos máximos que no resulten tan excesivos, y a que señale los criterios que los jueces deben aplicar para evaluar cuándo se está ante un plazo de detención judicial que no es razonable.

En abstracto, la posibilidad de que una detención preventiva dure tres o seis años, no resulta, a nuestro entender, compatible con el derecho al plazo razonable de duración de la detención judicial preventiva, ni con el derecho al plazo razonable de duración de un proceso que tiene toda persona involucrada en un litigio penal, incluidas las víctimas de los delitos cometidos o sus familiares. Ambos son derechos que se relacionan entre sí.

Debe tenerse presente que la Corte Interamericana de Derechos Humanos cuenta con importantes decisiones sobre estos temas que, a nuestro entender, han de ser consideradas por el tribunal.

Como ejemplo, se puede citar la sentencia sobre el fondo de la corte en el caso Genie Lacayo, en la que se constató que transcurrieron más de cinco años sin que se emita una sentencia firme desde la fecha en que se dictó el auto de apertura del proceso penal iniciado para investigar la muerte de esta persona, lapso que rebasaba los límites de la razonabilidad previstos en el artículo 8.1 de la Convención Americana ${ }^{52}$.

De otro lado, en el caso Suárez Rosero, reiteradamente citado en decisiones del Tribunal Constitucional, la corte señaló que el proceso penal seguido en contra de esta persona duró cuatro años y dos meses - entre la detención y la sentencia sobre la apelación final—, plazo que consideró contrario a la Convención ${ }^{53}$.

En el Perú, la duración prevista — a nivel legal— de la detención preventiva de hasta tres y seis años permite también tener una idea sobre la demora de los procesos judiciales. Para revertir esta situación se deben adoptar medidas de diferente tipo, no solo normativas ${ }^{54}$. Pero, bajo ninguna razón, tal demora puede justificar que se adopte un marco

52 Corte Interamericana de Derechos Humanos. Caso Genie Lacayo. Sentencia sobre el fondo del 29 de enero de 1997, parágrafo 81

53 Corte Interamericana de Derechos Humanos. Caso Suárez Rosero. Sentencia sobre el fondo del 12 de noviembre de 1997, parágrafo 73 .

54 Paradójicamente, en el fundamento 32 de la STC 3371-2004-HC (caso Miguel Sánchez Calderón), publicada el 2 de febrero de 2005, el tribunal señaló que «el hecho de no dictaminar o sentenciar (por parte de los jueces), intencionalmente, dentro de los plazos legales establecidos, con las consecuencias que ello conlleva y que ha puesto en tela de juicio la capacidad punitiva del Estado, merece sanción penal, la que deberá ser determinada por el legislador en el marco del Código Penal»». 
legal incompatible con los derechos que la Constitución y los tratados reconocen.

Finalmente, es importante anotar que, a pesar de existir un plazo máximo de detención judicial preventiva, si las circunstancias ya no justifican privar de libertad al inculpado, se debe proceder a su excarcelación. Así, bajo ninguna circunstancia, una detención puede sustentarse únicamente en la existencia de dicho plazo.

En caso contrario, se estaría ante lo que el Tribunal Constitucional ha calificado como una detención ilegítima, afirmación que ha sido sustentada en los informes 12/96 (párrafos 67 y 72) y 2/97 (párrafos 18 y 19) de la Comisión Interamericana de Derechos Humanos, de acuerdo a los cuales ${ }^{55}$ :

No se puede juzgar que un plazo de detención preventiva sea «razonable», per se, solamente basándose en lo que prescribe la ley. La detención sin condena puede no ser razonable aunque no exceda del plazo previsto legalmente. La razonabilidad debe estar fundada en la prudente apreciación judicial [...] En principio, la autoridad judicial tiene la obligación de asegurarse de que la prisión preventiva de un acusado no exceda un plazo razonable. Para tal efecto, debe analizar todos los elementos relevantes a fin de determinar si existe una necesidad genuina de mantener la prisión preventiva, y manifestarlo claramente en sus decisiones referentes a la excarcelación del procesado. La efectividad de las garantías judiciales debe ser mayor a medida que transcurre el tiempo de duración de la prisión preventiva.

La polémica en torno a la jurisprudencia del Tribunal Constitucional respecto del plazo máximo de detención judicial preventiva continúa hasta la actualidad ${ }^{56}$. Por su parte, el texto del nuevo Código Procesal Penal presenta cambios sustantivos sobre la materia, pues solo contempla plazos máximos de detención de nueve y dieciocho meses ${ }^{57}$. También dispone que corresponde ordenar la libertad del detenido ${ }^{58}$ vencidos dichos plazos. Si bien establece reglas para la prolongación de

55 STC 2915-2004-HC (caso Federico Berrocal Prudencio), publicada el 25 de noviembre de 2004, fundamento 37.

56 Se puede citar al respecto la STC 1680-2009-HC (caso Antauro Igor Humala Tasso y otros), publicada el 30 de julio de 2009, por medio de la cual se declaró infundada una demanda de hábeas corpus presentada contra resoluciones judiciales del Poder Judicial que extendían el plazo de detención judicial preventiva de diversas personas procesadas por los lamentables acontecimientos conocidos como «El Andahuaylazo», ocurridos en enero de 2005. En esta decisión, los magistrados que votaron en mayoría centraron sus argumentos en interpretaciones de índole legal de determinadas normas del Código Procesal Penal, así como en apreciaciones demasiado generales sobre determinados temas.

57 Código Procesal Penal de 2004, artículo 272: «Duración. 1.- La prisión preventiva no durará más de nueve meses. 2.- Tratándose de procesos complejos, el plazo límite de la prisión preventiva no durará más de dieciocho meses».

58 Código Procesal Penal de 2004, artículo 273: «Libertad del imputado: Al vencimiento del plazo, sin haberse dictado sentencia de primera instancia, el Juez de oficio o a solicitud de las partes decretará la inmediata libertad del imputado, sin perjuicio de dictar concurrentemente las medidas necesarias para asegurar su presencia en las diligencias judiciales, incluso las restricciones a que se refieren los numerales 2) al 4) del artículo $288^{\circ} »$.

EL DERECHO FUNDAMENTAL A LA LIBERTAD FÍSICA: REFLEXIONES A PARTIR DE LA CONSTITUCIÓN, EL CÓDIGO PROCESAL PENAL Y LA JURISPRUDENCIA DEL TRIBUNAL CONSTITUCIONAL 
la detención ${ }^{59}$, estas deberán ser concordadas en su momento con los actuales lineamientos jurisprudenciales del Tribunal Constitucional, que no ha previsto la posibilidad de que una detención judicial preventiva pueda durar más de treinta y seis (36) meses.

\section{V.4. Modificaciones al artículo 137 del Código Procesal Penal de 1991 y sentencia del Tribunal Constitucional}

En el año 2007, el Poder Ejecutivo expidió un conjunto de decretos legislativos orientados a fortalecer la lucha contra el crimen organizado, al amparo de las facultades delegadas por el Congreso de la República mediante la ley $29009^{60}$. Por medio del artículo 2 del decreto legislativo $983^{61}$ se incorporó un párrafo al artículo 137 del Código Procesal Penal, por medio del cual se agregaron criterios adicionales a tomarse en consideración para el cómputo del plazo legal de la detención judicial preventiva.

Dicho párrafo señala: «Cuando el delito se ha cometido a través de una organización criminal y el imputado pudiera sustraerse a la acción de la justicia o perturbar la actividad probatoria, la detención podrá prolongarse hasta por un plazo igual».

Como se aprecia, esta reforma legal permitía ampliar los plazos de detención por supuestos diferentes al de la obstrucción de la justicia por parte del procesado. En este sentido, en los casos en que procedía prolongar la detención por más de treinta y seis (36) meses era clara la contradicción entre esta norma y la jurisprudencia del Tribunal Constitucional. En su momento, la Defensoría del Pueblo señaló ${ }^{62}$ :

[...] tomando como referencia lo señalado por el Tribunal Constitucional respecto al segundo párrafo del artículo $137^{\circ}$, en este nuevo supuesto también se podrían extender los plazos de detención judicial preventiva a 18 meses (delitos seguidos en el procedimiento ordinario), a 36 meses (delitos seguidos en el procedimiento especial), y a 72 meses en el caso de los delitos de tráfico ilícito de drogas, terrorismo, espionaje y otros seguidos contra más de diez imputados, en agravio de igual número de personas, o del Estado.

Sin embargo, en el caso de situaciones que justifiquen ampliar el plazo de detención judicial preventiva más de 36 meses, la reforma del artículo 137 del Código Procesal Penal contradice lo señalado por el Tribunal Constitucional en su jurisprudencia, pues el hecho que el delito se haya

59 Código Procesal Penal de 2004, artículo 274: «Prolongación de la prisión preventiva.- 1. Cuando concurran circunstancias que importen una especial dificultad o prolongación de la investigación, y que el imputado pudiera sustraerse a la acción de la justicia, la prisión preventiva podrá prolongarse por un plazo no mayor al fijado en el numeral 2 del artículo $272^{\circ}$. El Fiscal debe solicitarla al Juez antes de su vencimiento".

60 Publicada el 28 de abril de 2007 en el diario oficial El Peruano.

61 Publicado el 22 de julio de 2007 en el diario oficial El Peruano.

62 Defensoría del Pueblo. Análisis de los decretos legislativos... Ob. cit., pp. 73-74. 
cometido «a través de una organización criminal» no se relaciona con la posible demora, atribuible al procesado, que pudiera existir en un proceso penal. Tampoco se relaciona con la gravedad que pueda generar contra el orden público un caso particular de tráfico ilícito de droga.

Por lo tanto, para la Defensoría del Pueblo, el artículo $2^{\circ}$ del decreto legislativo 983, en la parte que agrega un nuevo supuesto para prolongar la detención judicial preventiva por más de 36 meses, sin limitarla al supuesto de defensa obstruccionista o a casos particulares que generen graves perjuicios a la sociedad, es contraria a la jurisprudencia del Tribunal Constitucional.

Esta modificación del artículo 137 del Código Procesal Penal fue objeto de una demanda de inconstitucionalidad sobre la que el Tribunal se pronunció en el año 2010.

En ella, luego de resumir brevemente en qué consiste el derecho al plazo razonable de la detención judicial preventiva y las normas internacionales que lo reconocen, estableció los siguientes argumentos como sustento para declarar la norma impugnada como compatible con la Constitución y, en consecuencia, infundada la demanda ${ }^{63}$ :

[...] la prolongación de la investigación a que se hace referencia en el dispositivo modificado (del artículo 137을 del Código Procesal Penal) está motivado por circunstancias tales como la comisión del delito a través de una organización criminal, situación que es de especial dificultad o complejidad y afecta el desarrollo del proceso, por lo que se justifica dicho cambio legislativo.

De otro lado, dicha prolongación no queda librada al capricho o arbitrio del juzgador, dado que éste está en la obligación, por mandato constitucional — reiterado en la norma bajo análisis—, de motivar adecuadamente la decisión que expida en ese sentido, en los términos previstos por el artículo 139.5 de la Constitución.

Con estos argumentos - sin hacer mención alguna a su línea jurisprudencial anterior ni contrastar esta con la norma impugnada-, el tribunal declaró la constitucionalidad de la modificación efectuada al artículo 137 del Código Procesal Penal de 1991.

\section{5. Plazo razonable de detención y presunción de inocencia} El derecho al plazo razonable de la detención judicial preventiva se relaciona directamente con el derecho a la presunción de inocencia, reconocido en las normas internacionales sobre derechos humanos ${ }^{64}$, así

EL DERECHO FUN-

DAMENTAL A LA

LIBERTAD FÍSICA:

REFLEXIONES

A PARTIR DE LA

CONSTITUCIÓN,

EL CÓDIGO PRO-

CESAL PENAL Y LA

JURISPRUDENCIA

DEL TRIBUNAL

CONSTITUCIONAL 
como en el artículo 2, inciso 24, literal e, de la Constitución de $1993^{65}$. En virtud de este derecho, el Estado debe tratar al imputado de forma tal que las restricciones a sus derechos se reduzcan al mínimo necesario para el desarrollo de los fines del proceso penal.

Como ha señalado la Corte Interamericana de Derechos Humanos, el respeto a la presunción de inocencia implica «la obligación estatal de no restringir la libertad del detenido más allá de los límites estrictamente necesarios para asegurar que no impedirá el desarrollo eficiente de las investigaciones y que no eludirá la acción de la justicia, pues la prisión preventiva es una medida cautelar, no punitiva ${ }^{66}$.

La relación de la presunción de inocencia con el plazo de detención judicial preventiva es, por lo tanto, incuestionable. El propio Tribunal Constitucional ha señalado que el derecho a que la detención judicial preventiva no exceda de un plazo razonable es porque:

[...] viene dado por el adecuado equilibrio entre los dos valores que se encuentran en contrapeso al momento de aplicar la medida: por una parte, el deber del Estado de garantizar la expedición de sentencias penales justas, diligentes y plenamente ejecutables; y por otra, el derecho de toda persona a la libertad personal y que se presuma su inocencia, mientras no se declare judicialmente su culpabilidad.

Entre los argumentos, que el tribunal ha tomado como referencia, para pronunciarse en este sentido, se encuentran los criterios señalados por la Comisión Interamericana de Derechos Humanos ${ }^{67}$ en similar dirección.

\section{DERECHO A LA PROTECCIÓN JUDICIAL DE LA LIBERTAD FÍSICA}

Las normas internacionales sobre derechos humanos reconocen el derecho de toda persona a contar con un medio de protección judicial de sus derechos fundamentales. Así lo establece la Declaración Universal de Derechos Humanos (artículo 8), el Pacto Internacional de Derechos Civiles y Políticos (artículo 2, inciso 3), la Declaración Americana de los

65 Esta norma señala que toda persona es considerada inocente mientras, judicialmente, no se haya declarado su responsabilidad.

66 Corte Interamericana de Derechos Humanos. Caso Suárez Rosero, sentencia del 12 de noviembre de 1997, parágrafo 77. Sobre la base de esta argumentación, la Corte Interamericana estableció la responsabilidad del Estado del Ecuador que, al mantener privada de libertad a una persona más de tres años y diez meses cuando la ley penal establecía un máximo de dos años como pena para el delito que se le imputaba, afectó su derecho a ser juzgado dentro de un plazo razonable o ser puesto en libertad.

67 STC 2915-2004-HC. Caso Federico Berrocal Prudencio. Publicada el 25 de noviembre de 2004 , fundamentos 11-13. En esta decisión el tribunal cita el siguiente extracto (parágrafo 78) del informe 12/96 de la Comisión Interamericana: «[...] el principio de legalidad que establece la necesidad de que el Estado proceda al enjuiciamiento penal de todos los delitos, no justifica que se dedique un período de tiempo ilimitado a la resolución de un asunto de índole criminal. De otro modo, se asumiría de manera implícita que el Estado siempre enjuicia a culpables y que, por lo tanto, es irrelevante el tiempo que se utilice para probar la culpabilidad». 
Derechos y Deberes del Hombre (artículo 25) y la Convención Americana sobre Derechos Humanos (artículo 25).

Existen, asimismo, disposiciones específicas sobre el derecho a contar con un medio de protección judicial de la libertad física. En este sentido, el Pacto Internacional de Derechos Civiles y Políticos (artículo 9, inciso 4) señala: «Toda persona que sea privada de libertad en virtud de detención o prisión tendrá derecho a recurrir ante un tribunal, a fin de que éste decida a la brevedad posible sobre la legalidad de su prisión y ordene su libertad si la prisión fuera ilegal».

Por su parte, la Convención Americana sobre Derechos Humanos (artículo 7, inciso 6) establece: «Toda persona privada de libertad tiene derecho a recurrir ante un juez o tribunal competente, a fin de que éste decida, sin demora, sobre la legalidad de su arresto o detención y ordene su libertad si el arresto o la detención fueran ilegales».

El mecanismo tradicional de protección judicial de la libertad física es el proceso de hábeas corpus. Incluso, en el sistema interamericano de protección de los derechos humanos se equipara este proceso con el derecho reconocido en el artículo 7, inciso 6, de la Convención Americana ${ }^{68}$.

Respecto al hábeas corpus, la Constitución de 1993 precisa en su artículo 200, inciso 1, que este proceso «procede ante el hecho u omisión, por parte de cualquier autoridad, funcionario o persona, que vulnera o amenaza la libertad individual o los derechos constitucionales conexos».

La normativa legal que estuvo vigente entre 1982 y 2004 sobre el proceso de hábeas corpus comprendió varias disposiciones. La norma principal fue la ley 23506 (1982), que fue objeto de diferentes modificaciones, algunas de las cuales intentaron restringir la posibilidad de iniciar este proceso en determinadas circunstancias.

Así, por ejemplo, el artículo 6 del decreto ley 25659 (1992) impedía la presentación del hábeas corpus a favor de las personas acusadas de la comisión del delito de terrorismo. Si bien esta norma fue derogada por el artículo 2 de la ley 26248 (1993), el Tribunal Constitucional resolvió un caso donde dicha norma fue aplicada a pesar de que ya no se encontraba vigente.

En su decisión, consideró que las instancias del Poder Judicial que resolvieron el hábeas corpus infringieron el artículo 139, inciso 3, de la Constitución, relativo al derecho a la tutela jurisdiccional, puesto que impidieron inconstitucionalmente el acceso legítimo a la protección constitucional de la libertad personal a través del hábeas corpus. En esta decisión, el tribunal dejó establecido como principio a observar que

EL DERECHO FUNDAMENTAL A LA LIBERTAD FÍSICA: REFLEXIONES A PARTIR DE LA CONSTITUCIÓN, EL CÓDIGO PROCESAL PENAL Y LA JURISPRUDENCIA DEL TRIBUNAL CONSTITUCIONAL 
«ninguna autoridad puede impedir el ejercicio de las acciones de garantía por los particulares cuando se produzcan hechos que amenacen o violenten sus derechos constitucionales» ${ }^{69}$.

En el marco de otro proceso de hábeas corpus, el Tribunal Constitucional consideró inconstitucional el artículo 17 del decreto legislativo 824 (Ley de Lucha contra el Narcotráfico de 1996) —en tanto lo calificó como atentatorio al derecho a la tutela judicial efectiva- al establecer que una persona acusada de dicho delito no podía presentar un hábeas corpus si su privación de libertad, a pesar de efectuarse sin orden judicial ni en flagrante delito, era realizada en presencia de un representante del Ministerio Público ${ }^{70}$.

La actual regulación del proceso de hábeas corpus se encuentra prevista en el Código Procesal Constitucional, vigente desde diciembre de 2004. A través de su jurisprudencia, el tribunal ha precisado el ámbito de protección de este proceso constitucional y ha llegado, incluso, a establecer una tipología de hábeas corpus, que debe ser entendida estrictamente como orientadora ${ }^{71}$.

\section{VII.REFLEXIONES FINALES}

La libertad física es un derecho fundamental reconocido en la Constitución de 1993 y en los instrumentos internacionales sobre derechos humanos, cuyos alcances, contenidos y límites han merecido un importante desarrollo en la jurisprudencia del Tribunal Constitucional peruano.

Como se ha tenido oportunidad de apreciar a lo largo de este trabajo, este presenta tendencias claramente delimitadas, aunque no siempre con argumentos convincentes desde una perspectiva jurídico-constitucional. En los casos que han constituido la base de sus pronunciamientos queda de manifiesto la permanente tensión entre el respeto de la libertad física y las demandas a favor de una mayor severidad para garantizar el orden público, que por lo general se concreta con la mayor limitación del ejercicio de los derechos fundamentales.

Especial atención merece el hecho que el tribunal haya precisado la necesidad de respetar la normativa constitucional en virtud de la cual la privación de la libertad física solo procede en los casos en que exista una orden judicial o flagrante delito. De igual forma, ha ratificado la importancia de la estricta observancia de los plazos previstos para que una persona privada de libertad sea conducida ante las autoridades judiciales.

En temas vinculados con la detención judicial expedida en el marco de los procesos penales, la jurisprudencia del tribunal ha remarcado la 
necesidad de respetar su carácter excepcional y fundamentar consistentemente las resoluciones judiciales por medio de las cuales se decide aplicar esta medida cautelar.

Respecto del derecho al plazo razonable de la detención judicial preventiva, las decisiones del tribunal han estado centradas principalmente en el respeto de los plazos máximos de detención judicial previstos en la legislación procesal penal. Asimismo, ha establecido claramente la imposibilidad de que se impida el inicio de un proceso de hábeas corpus a través de una norma, cuyo objetivo principal es la protección judicial de la libertad física.

Si tomamos en cuenta la aplicación progresiva del Código Procesal Penal de 2004, corresponde a los operadores jurídicos evaluar la compatibilidad entre este nuevo marco normativo y los lineamientos jurisprudenciales del Tribunal Constitucional. Desde nuestro punto de vista, salvo en temas específicos pero de especial importancia — como el de la duración de la detención judicial preventiva-, existe concordancia entre ambas fuentes, por lo que no se debe esperar cambios sustantivos sobre la materia, sino solo el real y efectivo respeto de las garantías y facultades mínimas inherentes al derecho fundamental a la libertad física.

EL DERECHO FUNDAMENTAL A LA LIBERTAD FÍSICA: REFLEXIONES

A PARTIR DE LA

CONSTITUCIÓN, EL CÓDIGO PROCESAL PENAL Y LA JURISPRUDENCIA DEL TRIBUNAL CONSTITUCIONAL 